\title{
The Practice of Innovation and Entrepreneurship Education in Polytechnic Colleges under the New Normal of "Internet Plus"
}

\author{
Xiangrui Meng \\ Applied Technology College of Dalian Ocean University \\ Liaoning, Dalian 116300
}

\author{
Yan Song \\ Dalian Wafangdian Normal School \\ Liaoning, Dalian 116300
}

\begin{abstract}
Supply-side structural reform" and "mass entrepreneurship and innovation" are important tasks that our government is promoting at present. Under the new normal of "Internet plus", these two tasks have a close connection, yet certain differences. Innovation and entrepreneurship work carried out in polytechnic colleges alongside structural reform on the supply side can accurately locate deficiencies in driving force, resource allocation and industrial structure of the task. Think from the perspective of supply-side structural reform, efforts should be made to improve resource optimization, education, and investment and financing channels, which are conducive to improving the performance of innovation and entrepreneurship education in polytechnic colleges.
\end{abstract}

Keywords-Internet plus; Innovation and entrepreneurship education; supply-side reform; polytechnic colleges; practice

\section{INTRODUCTION}

Supply-side structural reform and innovation and entrepreneurship education are important tasks that our government is currently pushing forward. As an important decision for economic restructuring in China at the present stage, and also an important way to achieve innovation and entrepreneurship education, the supply side structural reform refers to restructuring the supply-side while moderately increasing the demand so as to increase the quality and efficiency of the supply[1]. With the advancing of "mass entrepreneurship and entrepreneurship," higher demands of the polytechnic college students have been put forward. As the main platform for the innovation education work, colleges and universities should keep up with the trend of the times to master the current status of innovation and entrepreneurship work, make bold innovations, and improve the personnel training mechanism, so that innovation and entrepreneurship education can be deeply integrated with supply-side reform.

\section{FINDING THE INTERFACE BETWEEN SUPPLY-SIDE REFORM} AND INNOVATION AND ENTREPRENEURSHIP EDUCATION IN

POlyTeChNic COLLEgES UNDER THE NEW NORMAL OF "INTERNET PLUS"

Innovation and entrepreneurship education is a issue concerning the education and development of college students, while supply-side reform is closely related to economic development of our country. On the surface, these two tasks do not seem to have the necessary relations, but in reality they are tightly integrated and even inseparable from each other in the progress of the society and the whole country. Centering on quality improvement, the supply-side reform uses some relevant means to match supply with demand, so as to promote the fairness and scientificity of resource allocation [2]. College students' innovation and entrepreneurship means that college students engage in product development, team building, and professional services relying on their professional capabilities. Comparing with social entrepreneurs, college students are highly innovative.

The bridge between the two policies needs to be developed from the four elements of supply-side reform: innovation, land resources, labor, and capital. First, innovation and entrepreneurship work requires a large number of high-quality personnel and entrepreneurial teams that master the market dynamics work well in collaboration and are innovative. Second, it is unavoidable to encounter funding shortages and high entrepreneurial costs during the launching of innovation startups, thus the low-cost innovation and entrepreneurial condition, and necessary supports from society, government, and schools are required. The third is funding. For college students, funding is the primary challenges in business startups. Therefore, the society, government, and enterprises should provide them with financial support. The fourth is innovation. It is the closest connection between the two policies. Structural optimization and high-quality supply in supply-side reform need to be achieved by innovative products. Therefore, though the contents of the policies are different, the concepts are the same. Innovation and entrepreneurship education can only be successfully carried out under the guidance of supply-side reform.

\section{APPLYING "INTERNET THINKING" TO REFRESH BACKWARDS CONCEPT IN INNOVATION AND ENTREPRENEURSHIP EDUCATION}

Internet is no longer just a technology, but has evolved into a thinking paradigm, that is, the "Internet thinking" which industries are keen to discuss currently. Internet thinking is not only about transforming traditional marketing, product development, traditional institutional and business models, but also even remodeling our thinking patterns. 


\section{A. Internet thinking-user thinking: Centering on students, and cultivating service awareness}

The user thinking is that instead of understanding superficially the users whom you are serving, deeply analysis should be made with user's needs as the starting point. Only then, can we survive the fierce competition. As the core of the Internet's thinking, the user's thinking runs through the operation of the company. It is also applicable to our innovation and entrepreneurship education. We need to cultivate an in-depth understanding and mastery of what students need to do for innovation and entrepreneurship. When launching innovation and entrepreneurship education, we should act according to circumstances, come down to earth and center on students. Only in-depth mastery of student needs can we better convoy along their innovation and entrepreneurship journey.

\section{B. Internet thinking-big data thinking: Guiding development by data laws}

Big data thinking refers to the understanding of the core competitiveness of enterprises - data assets. Corporate big data has become core assets and even core competitiveness. The business rule deduced by data analyzing provides support for the company's development decisions. This thinking is more applicable to efficient innovation and entrepreneurship education. Online education has mushroomed under the "Internet+" new normal, and the huge amount of education and teaching data generated by it will become the most valuable data resources. By data mining, we can find valuable teaching and learning rules hidden in the data. These rules will become an important basis for education, teaching, and management decision-making, and point out the direction of innovation and entrepreneurship education.

\section{Internet thinking-trans-boundary thinking:Strengthening cooperation among schools, enterprises and local governments}

The trans-boundary thinking refers to the understanding of the boundary of the industry and pioneering work. With the rapid development of the Internet and information technology, real economy has been mixing gradually with the virtual economy, resulting in the fuzzy borders of many industries. These industries can achieve win-win cooperation through the trans-boundary thinking of the Internet. The trans-boundary thinking should be mainly applied to school-enterprise cooperation, collaboration between colleges and local governments, and school-school cooperation. In other words, innovation and entrepreneurship education must truly meet the expected teaching goals and must integrate corporate resources and local government resources and the resources of colleges and universities at all levels, only then can innovation and entrepreneurship education realize the optimized guidance throughout the process that is from the initial consciousness guidance , theory accumulation, to campus training and social practice, and to our final training goals---the innovation and entrepreneurship.

\section{SUGGESTIONS ON INNOVATION AND ENTREPRENEURIAL Education of Polytechnic COLLEges UNDER THE NeW NORMAL OF 'INTERNET PLUS"}

\section{A. Talent cultivation based on majors}

The reform on innovation and entrepreneurship education in polytechnic colleges can be conducted in the following aspects.

Training the talents needed by the society according to positions, which is "from school to job", the S2P model. It can be illustrated by the order-based talent training model, which runs according to the requirements of the company.

Adopting the "online and offline" network talent training mode, including: (1) Online to offline. That is to say, combining classroom teaching with online courses, such as flipped classroom in which students learn in online courses while teachers guide in classroom, helping them with problems that cannot be solved by them. (2) Offline to online. Students are taught in class first, and then they are free to study online to supplement the knowledge they have learnt in class. (3) Offline to online to offline. Students study in the classroom first, then learn online, and finally return to the classroom to summarize and reflect on the content of the study.

In "student to student" (S2S) teaching mode, students set up internship groups by themselves and do entrepreneurial activities together, during which they will explore and think independently, and apply knowledge to practice [3].

In the "enterprise to school” (E2S) learning model, students sign an agreement with the company in advance. Before graduation, students will be trained by companies, work as internship that will turn into jobs after graduation.

Polytechnic colleges can realize the reform of the personnel training model only when they figure out their roles and devote themselves to the cultivation of the characteristics and personality of talents.

\section{B. Course teaching system based on market demand}

Professional courses must be adjusted according to the needs of the job, focusing on the cultivation of students' professional knowledge, not skills. Judging from the supply side, it is necessary to improve students' practical work ability, and the curriculum system needs to be constructed from the students' employment needs and quality requirements.

Scientific integration of personnel training structure. According to the requirements of the society for talents, we should carry out different levels of training, including the level of educational attainment and different types of personalized training.

Setting up professionals according to the needs of the market. Courses can't be opened based on the level of teachers' levels, but according to the actual market demand, and majors can't be divided too carefully. Failure to divide professions according to the needs of society will lead to an unclear distinction between industries and professions. Whereas there must exist clear divisions and convergence among professions. 
Training personnel according to the requirements of the industry. In this way, students can meet the employment standards and job requirements, so as to get familiar quickly with work, becoming the industry's innovative talents.

Setting majors dynamically. We need to follow tightly the dynamic movements in the market, establish an early warning exit mechanism, and implement the evaluation of the third party, so that the profession can meet the social development and needs. The profession with a relatively low employment rate for a long time should be cut down. We should find out the trend of changes in the demand for talents in various industries, and do not add new professions arbitrarily.

\section{Supply-side education reform under the new normal of "Internet plus"}

Although school-enterprise cooperation policies have been implemented, many companies still cannot truly participate in the cultivation of talents in polytechnic colleges. Through the "Internet plus", a talent training platform for universities and companies can be established to share information and allocate resources. Schools and enterprises can use the Internet platform to establish a talent cultivation system that includes professional standards, curriculum standards, and skill standards, to connect employers and students, schools and businesses. Given this, students can connect with companies through the Internet platform and understand the requirement of recruiting, which provides ideas for the training of talents in colleges, thus achieving high-efficiency and high-quality talents cultivation.

With vocational education groups, school-enterprise coalitions, and other measures, the company and the school are closely linked and a common platform for personnel training is established. This can promptly identify and solve the problem of incoherence between talent cultivation and employment. The joint efforts made by enterprise and school can keep the profession in line with the requirements of the society, improve the quality of the teaching staff, improve education and training, foster the cultivation of innovative and entrepreneurial talents, and conduct supply-side structural reform based on educational needs.

\section{Innovative personnel training methods}

Entrepreneurship education is centering on entrepreneurship. It aims to cultivate students' entrepreneurial psychology, quality, competence, and spread entrepreneurial expertise. It not only enables students to have basic entrepreneurial knowledge and ability, but also allows students to form correct entrepreneurial ideas.

Polytechnic colleges should establish education courses of innovation and entrepreneurship, provide relevant education for students, and integrate professional education with innovation and entrepreneurship education to improve students' entrepreneurial awareness and innovation ability. In the building of the innovation platform, they should actively take in social forces, carry out extra-curricular practice, and strengthen professional training and Internet entrepreneurship training for students. By holding 'Innovation and Entrepreneurship Alliance" on campus, an Internet platform can be established to promote exchanges and cooperation.
They should allow students to master the real entrepreneurial projects, and provide students with venture capital to solve funding difficulties in a bid to create a new look of "mass entrepreneurship and innovation" [4].

\section{E. Providing diversified educational resources}

As far as the market is concerned, the demand and supply of education are like the two sides of a coin [5]. When it comes to educational demand, education supply is the front side, and an internal factor in the process of talent cultivation. In terms of education supply, the demand is the front side, and it imposes certain restrictions on the cultivation of talents in polytechnic colleges.

Polytechnic colleges should raise their awareness of education supply, ensure that the education of talents is consistent with the goals of economic development in the future, and meet the needs of social development. They must take into account the development of the industry when setting majors, and cultivate a proactive sense of personnel training. What's more, we should promote coalition of schools and enterprises by encouraging enterprises to participate in the school's personnel training, improve students' professional qualities, and offer effective supply, training high-quality innovative talents [6].

We need to cultivate international education supply awareness, encourage social capital to participate in the career development of talents to add vitality to polytechnics education. Judging from the current situation in China, it is necessary to draw on and introduce foreign high-quality educational resources. At the same time, we must also have personalized education supply awareness. Teacher teams should be expanded based on the actual needs of colleges and universities. Schools can carry out different forms of student activities and community organizations to build a resource pool for the cultivation of talents.

\section{REFERENCES}

[1] Zhang Xinyu. Analysis of the Reform of Western Economics Teaching in Polytechnic Colleges That Integrating the Entrepreneurship Education and Professional Education [J]. The Journal of Jilin Radio and TV University,2017,(11):10-12+59.

[2] Chen Nan. Analysis of the "Four Integrations and Five Advances" System of Innovation Education in Colleges and Universities under the New Condition of Economy[J]. Modern Economic Information, 2017,(17):394-395+412.

[3] Zhang Ying, Liu Huan, Li Haobo. The Status Quo of Innovation and Entrepreneurship Education in Colleges and Universities and the Exploration of the Reform Path[J]. Modern Economic Information, 2017, (02):381-382.

[4] Chen Nan. Strengthening "Innovation and Entrepreneurship" Education is the Breaking Point for Deepening the Supply-side Reform on Talent Training [J]. Modern Economic Information, 2016,(23):384-385.

[5] Zhang Lechun, Wang Shuiming, Gu Weibin, Sun Jiafeng. Perfecting the Innovation Condition and Promoting the Supply-Side Reform of Higher Education [J]. Modern Economic Information 2016,(22):354-355.

[6] Li Hai. Analysis of Supply-side Reform of Polytechnic Education in the Background of Innovation and Entrepreneurship[J]. Chinese Vocational and Technical Education, 2016,(32):98-101. 